\title{
Experimental linguistics in aphasia and child language
}

\author{
Maria Irma Hadler Coudry, Isabella de Cássia Netto Moutinho \\ Department of Linguistics, State University of Campinas, Brazil \\ https://doi.org/10.36505/ExLing-2019/10/0028/000390
}

\begin{abstract}
The discursive approach of language studies in aphasia and childhood is the theme of this text and derives from classical studies (Jakobson, 1941). Such perspective is based on the theoretical-methodological assumptions postulated by Discursive Neurolinguistics, which aggregates authors who study language and brain in action, its functioning, normal and pathological. Experimental activities (which do not include standardized tests) are analysed, in different discursive genres, produced along with longitudinal studies of aphasics and children in (re)acquisition of speech and writing. Such data happen in different discursive situations, the way language works in our society. Language is seen as work and action between interlocutors, incomplete, heterogeneous and polysemic. The data confirm the classic hypothesis of the relation between aphasia and child language.
\end{abstract}

Key words: language, aphasia, children, speech, writing.

\section{Language, brain and subject}

Our language conception is postulated by Franchi (2002), who conceives it as a constitutive activity and as a work, a historical product of the relationship between speakers, which meaning depends on a set of aspects, not put beforehand, but conditioned on who speaks, with whom, under certain circumstances, wondering what, etc. Thus, we reinforce the creative possibility of language, the force that moves saying, repeating, meaning. From this conception derives a subject that deals with language, captured by it (De Lemos, 2002).

An incomplete subject, in need of the other and determined by devices (Foucault, 1969; Agamben. 2009) that define actions, language and gestures. A subject who works the language, in interactions with his others, even as aphasic, even as a child. The conception of the brain we take is the one from Soviet Psychology, (Vygotsky, 1926; Luria, 1981), which conceives it from a historical point of view, the product of human action inserted in a culture and shared by a society.

A hierarchically functioning brain that articulates its areas and zones for the complexity of the activity the subject performs. According to Luria (1981), there are definite roles in terms of relationships between brain areas which derive from learning and use (automated and creative) that rely on

ExLing 2019: Proceedings of $10^{\text {th }}$ International Conference of Experimental Linguistics, 25-27 September 2019, Lisbon, Portugal 
114 M.I. Hadler Coudry, I.C. Netto Moutinho

neuroplasticity, inherent to an incomplete system and subject to new configurations.

\section{Methodology}

The methodology we use in ND is heuristic, based on discovery procedures that the researcher, theoretically oriented, proposes as activities with language. Once it is discursively oriented, not based on standard tests (Coudry 1986, 2018), which activities are always the same for different subjects, our activities may vary from subject to subject and the solutions they find may also differ. It is important, in the interaction with the subject, that he understands what is required of him, that is, that what is proposed makes sense to him. This methodology is not ready (like a test), but the theoretical foundations that support it are so established and solid that the researcher proposes and adjusts the activities for each subject. Interestingly, it is a process of discovery that feeds the theoretical researches that, in turn, expand the methodological possibilities. What is experimental about our approach is the possibility of proposing experiments with the language to help the subject, that is, that contribute to the researcher and to the subject to deepen their knowledge about the difficulties and the possible solutions. Language experiments for aphasics and children ${ }^{1}$ are conducted for the purposes of understanding both the difficulties and possibilities for a problem to be solved (solving problems: hypothesis, execution, verification).

Writing: similar processes

This first experiment relates a child trying to fill in a crossword- the word gema, which means egg yolk. MT is a child that has attended Ccazinho because of his school difficulties. He is at the age of 12, at the sixth grade and still hasn't learnt to read and write. First, MT writes gma and realizes that something is wrong, because there is a crossword field left to fill in. He points his finger at the letter $\mathrm{G}$ and reads $(\mathrm{g})$, then points the letter $\mathrm{E}$, and reads (ma). The letter $\mathrm{G}$, because its name coincides with the sound of the syllable to be written, leads MT to write only the consonant, without spelling out the core of the syllable. The investigator's intervention is that MT disentangles himself from the name of the letter to write the syllable GE (Coudry 2010, Coudry Bordin 2012, Barthelson 2014). We present now the data of an aphasic subject, RS, who goes through the same process in his reentry in writing (Coudry, Freire, Gomes 2006). In writing his mother's name (Rosangela) omitted the syllable core, because the vowel $(\mathrm{E})$ is in the letter name $(\mathrm{G})$. He writes ROSANG LA and leaves a blank space between the letters $(G)$ and $(L)$.

In order to write the full mother's name and to write the word gema, both the child and the aphasic must erase the sound image of the letter $G$ to be able to write the letter E. In the child's case, the perception that a second writing is needed is the activity itself, which is the crossword - there is an empty place to be filled. In the case of the aphasic, the reading of what he wrote and the mark 
of the blank space were fundamental for him to understand the adjustment he would need to make.

The Discursive Neurolinguistics researches has also found out other kinds of similarities through other different kinds of language experiments:

In phonology, entering the alphabetic system, using speech, relating sound and letter; in prosody - when the response intonation does not match to its content but repeats the speaker's words. In morphology, when derivation processes act in the formation of words: child says arrumeira and not arrumadeira (maid) and aphasics say gentoas and nor gente (people). In syntax: the aphasic says menino trem (boy train) and child the child says Pedro duiche (Pedro (sand)wich) which shows that they preferentially say names to express the action between name and verb. In semantics, when the child seeks meanings of new words and aphasic produces paraphasias (gentoas) as well as metonymic descriptions (that which shows our legs - trying to define bermuda). In discourse: when the reversibility of discursive roles is done by repeating the other's speech Question: Do you go? Answer: You go.), which shows no personal implications. All in all, the longitudinal follow up of aphasics and children, we can find data (Courdry 1996) - which illuminates the speaking, writing and reading processes and exposes the discursive event, moving theorizing and advancing the analysis.

\section{Conclusions}

The data confirm the classic hypothesis about the interrelationship of aphasia with childhood language, strongly indicating that the transformations that aphasia causes in speech, reading and writing resume childhood language processes, or that incomplete childhood processes occur again in aphasia. There is, therefore, much similarity between processes that occur in language changes in aphasia, predicted in the language itself, that co-occur in language acquisition, that is, in the two poles of human life. The ND approach brings discursive practice as a methodological resource - in which experiments with language can be included - which, unlike tests, not only points the child's and aphasic limits with speech, reading and writing, but also possibilities of intervention, which are different from the traditional clinical and pedagogical approach. which disregard the various faces of the subject of language: historicity, psychoaffectivity and singularity. Thus, the inevitable encounter between aphasia and childhood offers an approach that revolutionizes the old approaches to language assessment and intervention.

\section{Notes}

The functioning of these Centers (the first one aimed at aphasics and the second one for children and young people with learning difficulties, especially reading and writing, and speech is also considered) is based on verbal and nonverbal discursive practices that make sense to participants who live together. themselves systematically and who recognize themselves as a group of people and as speakers 
of a natural language for sharing, with differences, cultural parameters (history, habits, values, beliefs, artefacts, devices, etc.) that guide what is spoken, write, read.

\section{References}

Aganbem, G. 2009. O que é contemporâneo? E outros ensaios. Chapecó: Argos.

Barthelson, B. 2014. Relações de sentido no processo de aquisição e uso da leitura e da escrita. Dissertação de mestrado. Campinas, IEL/Unicamp.

Coudry, M. 1986. Diário de Narciso: discurso e afasia. Tese de Doutorado. Campinas, IEL/Unicamp.

Coudry, M O que é dado em Neurolinguística? In: CASTRO, M. F. P. (Org.), Método e o Dado no Estudo da Linguagem. Campinas: Editora da Unicamp, 1991/1996, pp. 179-194.

Coudry, M. 2018. Diário de Narciso e Neurolinguística Discursiva: 30 anos depois. Cadernos De Estudos Lingüísticos, 60(2), 323-350.

Coudry, M; Freire, F.; Gomes, T. 2006. Sem falar, escrever e ler e ainda sujeito da linguagem. Estudos Lingüísticos XXXV, p. 1375-1384. Grupo de Estudos Linguísticos, Brasil.

Coudry, M., Bordin, S. 2012. Afasia e infância: registro do (in)esquecível. Cadernos de Estudos Linguísticos, 54 (1) Campinas, UNICAMP.

Coudry, M. 2010. Relatório de Pesquisa: Projeto Integrado em Neurolinguística: avaliação e banco de dados. CNPq/301726/2006-0, 65p. Impresso. 2010.

De Lemos, C. 2002. Das vicissitudes da fala da criança e de sua investigação. Cadernos de Estudos Linguísticos, p. 41-69. Campinas, IEL/Unicamp.

Foucault, M. Arqueologia do Saber. Petrópolis Lisboa: Vozes, 1969.

Franchi, C. 2002. Linguagem: atividade constitutiva. Cadernos de Estudos Linguísticos, $\mathrm{n}^{\circ}$ especial, 37-74.

Jakobson, R. 1941. Langage enfantin et aphasie. 1ère. Edition. Paris, Flammarion.

Luria, A. 1981. Fundamentos de Neuropsicologia. 1a ed. São Paulo, EDUSP.

Vygotsky, L. 2004. Psicologia Pedagógica. São Paulo, Martins Fontes. 